\title{
Plantacje nasienne drzew leśnych w Polsce
}

\author{
Jan Kowalczyk*, Marek Rzońca \\ Zakład Hodowli Lasu i Genetyki Drzew Leśnych, Instytut Badawczy Leśnictwa \\ ul. Braci Leśnej 3, Sękocin Stary, 05-090 Raszyn \\ *j.kowalczyk@ibles.waw.pl
}

\section{Streszczenie}

Lasy zagospodarowane przez leśników są miejscem wypoczynku, pełnią rozliczne funkcje ochronne i społeczne, lecz są również źródłem produkcji drewna i innych użytków. Zapewnienie trwałości użytkowania drewna jest powiązane nierozerwalnie z rozpoznaniem i ulepszaniem wartości genetycznej i hodowlanej drzew leśnych oraz z jakością wytwarzanego i użytkowanego surowca drzewnego. Podstawowym narzędziem realizacji tych zadań jest hodowla selekcyjna drzew leśnych, a jednym z kluczowych ogniw łańcucha prac selekcyjnych są plantacje nasienne. W przeglądowym artykule zaprezentowano stan plantacji nasiennych w Polsce i ich grupowanie według znaczenia dla gospodarki leśnej. Prezentujemy fakty historyczne dotyczące powstania idei plantacji i jej realizacji w leśnej praktyce hodowlanej. Gospodarując na plantacjach z jednej strony dbamy o zmienność genetyczną, a z drugiej strony staramy się uzyskać jak największy zysk genetyczny. Są one efektywne i ekonomicznie opłacalne, w porównaniu do tego, jakie zadanie mają do wypełnienia w leśnictwie. Jak wynika z analiz ekonomicznych zwiększenie kosztów produkcji sadzonek, w związku z użyciem nasion z plantacji nasiennych, nie przekracza 3\%. Zdaniem autorów plantacje nasienne są najbardziej racjonalną i najmniej ekologicznie wątpliwą drogą do poprawy produkcji leśnej.

\section{Slowa kluczowe}

plantacje nasienne, hodowla selekcyjna drzew leśnych, zysk genetyczny, bioróżnorodność, klasyfikacja plantacji nasiennych

\section{Wstęp}

Plantacje nasienne to grupy drzew wyselekcjonowanych i zagospodarowanych w taki sposób aby minimalizować dopływ pyłku do nich ze źródeł zewnętrznych (Chałupka et al. 2011: 16 ). Celem plantacji nasiennych jest uzyskanie obfitych zbiorów łatwych do pozyskania nasion o podwyższonej wartości genetycznej. Plantacje nasienne są elementem gospodarki leśnej. Lasy są miejscem wypoczynku, pełnią funkcje ochronne i społeczne a także są miejscem pracy, źródłem produkcji drewna i innych użytków. Zapewnienie trwałości użytkowania drewna jest powiązane nierozerwalnie z rozpoznaniem i ulepszaniem wartości genetycznej i hodowlanej drzew leśnych oraz z jakością wytwarzanego i użytkowanego surowca drzewnego. Podstawowym narzędziem realizacji tych zadań jest hodowla selekcyjna drzew leśnych, a jedno z kluczowych ogniw łańcucha prac selekcyjnych to plantacje nasienne. Słowo plantacja kojarzy się z intensywną uprawą drzew, która niewiele ma wspólnego z lasem 
wielofunkcyjnym. Inaczej jest z plantacjami nasiennymi, które są w rzeczywistości sadami nasiennymi, przyjaznymi dla środowiska i dostarczają udoskonalonych genetycznie nasion dla odnowień i zalesień. Gospodarując na plantacjach z jednej strony dbamy o zmienność genetyczną, a z drugiej strony staramy się uzyskać jak największy zysk genetyczny. Jak wykazały badania genetyczne uprawy powstałe z nasion zebranych w plantacjach nasiennych charakteryzują się podobną zmiennością genetyczna, jak uprawy powstałe $\mathrm{z}$ nasion pochodzących z drzewostanów (Ivetić et al. 2016: ). W niektórych wypadkach nasiona pochodzące z plantacji nasiennych są bardziej różnorodne, bo rosnące tam drzewa mają doskonałe warunki, aby mogły się wzajemnie zapylać (Chybicki, Burczyk 2013: 561-574). Pomimo izolacji do plantacji dociera wiele pyłku obcego i nawet do 50\% ojców pochodzi spoza plantacji. Mimo tego z uwagi na obawy o zawężenie zmienności genetycznej drzew w Polsce, w okresie realizacji programu hodowli selekcyjnej do 2010 r. nasiona z plantacji mogły być wykorzystywane do zakładania upraw, ale tylko jako domieszka nie większa niż 20\%, upraw pochodnych $\mathrm{z}$ plantacji nasiennych oraz upraw rozproszonych. W nowym „Programie zachowania leśnych zasobów genowych i hodowli selekcyjnej drzew w Polsce na lata 2011-2035" (Chałupka et al. 2011: 49) odsetek ten zwiększono stawiając sobie za cel osiągnięcie do 2035 roku przynajmniej 40\% wykorzystania nasion z plantacji nasiennych w odnowieniach i zalesieniach, zalecając zakładanie normalnych upraw gospodarczych z nasion z plantacji nasiennych. Nasze plantacje nasienne powstały na bazie drzew matecznych wyselekcjonowanych fenotypowo. Plantacje nasienne są także bardzo cennymi obiektami chroniącymi zmienność genetyczną drzew leśnych, stanowiąc swego rodzaju banki genów in-vivo. Celem naszej publikacji jest przybliżenie zagadnień związanych $\mathrm{z}$ tworzeniem i utrzymaniem plantacji nasiennych, przytoczenie ich historii oraz wskazanie ich miejsca w leśnictwie.

\section{Historia plantacji nasiennych}

Historia rozwijania się koncepcji i zakładania plantacji nasiennych jest niełatwa do odtworzenia, gdyż przebiegała wielotorowo. W opracowaniu Feilberga i Søgaarda z Arboretum Hørsholm w Danii, jest przedstawiona historia tworzenia i wykorzystywania plantacji nasiennych (Faulkner 1975: 1-18o). Jak podają ww. autorzy, plantacje nasienne po raz pierwszy zostały zdefiniowane w 1956 roku przez Syrach Larsena jako „ogrody nasienne”. Definicję tę uszczegółowił Zobel (Zobel et al. 1958: 815-825), a następnie została ona $\mathrm{z}$ niewielkimi zmianami oficjalne przyjęta przez organizację OECD (2001: 1-28). Pierwsze plantacje nasienne powstały jednak znacznie wcześniej na wyspie Jawa. Już około 188 o roku zakładali je tam Duńczycy w celu podniesienia zawartości alkaloidów w korze chinowca, z którego wyrabiano chininę. Wykorzystanie plantacji nasiennych było powszechną praktyką w Malezji od 1919 roku w selekcji drzew kauczukowca. Jednak w tym okresie trudno było jednoznacznie rozgraniczyć obszary do produkcji nasion do odnowień i zalesień, od plantacji nasiennych, których celem była produkcja genetycznie udoskonalonych nasion drzew leśnych. W Europie pierwsze plantacje nasienne powstały w 1931 roku w Wielkiej Brytanii. Większość plantacji została założona jednak dopiero po II wojnie światowej (Faulkner 1975: 1-180). Pierwsza plantacja modrzewia powstała w 1946 roku w Szwecji. Według danych Instytutu Badawczego Leśnictwa najstarsza plantacyjna uprawa nasienna w Polsce, zlokalizowana w Nadleśnictwie Wyszków, pochodzi z 1967 r. Najstarsze plantacje nasienne w lasach gospodarczych powstały w 1970 roku w Nadleśnictwach Brzeziny i Supraśl. Jednak pierwsze doświadczalne plantacje nasienne założono w Kórniku 1964 r. na terenach należących do Instytutu Dendrologii Polskiej Akademii Nauk. Od tego czasu powstało wiele plantacji nasiennych w Polsce początkowo dla gatunków iglastych a począwszy od lat osiemdziesiątych ubiegłego wieku również dla liściastych. 


\section{Klasyfikacja plantacji nasiennych}

Sposoby zakładania i prowadzenia plantacji nasiennych oraz stopień ich wykorzystania w hodowli lasu są różne jak też różne jest ich znaczenie. Jednym z kryteriów klasyfikacji plantacji nasiennych jest ich pokrewieństwo. Uwzględniając pokrewieństwo drzew dzielimy je na plantacje klonalne (wegetatywne), u nas nazywane plantacjami nasiennymi $(\mathrm{PN})$, oraz powstałe na drodze generatywnej z nasion drzew matecznych, dla których przyjęła się nazwa plantacyjne uprawy nasienne (PUN). Porównując PN i PUN można wyróżnić mocne i słabe strony tych obiektów. Wyhodowanie materiału dla założenia PN jest trudniejsze i wymaga większych nakładów. Za PN przemawia jednak to, że drzewa tam rosnące są dokładną kopią genotypu drzewa matecznego i pozwalają na osiągniecie większego zysku genetycznego. Plantacje generatywne (PUN) zapewniają natomiast większa różnorodność, chociaż mniejszy zysk genetyczny. Są one łatwiejsze do założenia oraz nie ma na nich problemów z odrzucaniem zrazów (części szczepionej, która pochodzi od drzewa matecznego) przez podkładki (rośliny na której szczepimy). PUN mogą spełniać role testów rodowych i być wykorzystywane przy ocenie wartości hodowlanej drzew matecznych (Kowalczyk 20o8: 126-134). Wszystko to decyduje o tym, ze PN i PUN uzupełniają się wzajemnie i zarówno jedne, jak i drugie, są w Polsce równie powszechne. W innych krajach częstsze są plantacje wegetatywne. Porównanie PN i PUN przytoczono na wstępie, aby zaznaczyć odmienność tych obiektów. W większości przypadków jednak zabiegi i prace hodowlane na plantacjach wegetatywnych i generatywnych są podobne. Plantacje można też podzielić na produkcyjne i zachowawcze. Plantacje produkcyjne dostarczają nasion udoskonalonych genetyczne, zaś plantacje zachowawcze służą przede wszystkim do zachowania cennych genotypów poza miejscem ich naturalnego występowania, przy okazji produkując nasiona.

Ze względu na sposób zagospodarowania i prowadzenia plantacji nasiennych można wskazać grupę obiektów intensywnie zagospodarowanych, które są przycinane i poddawane formowaniu koron. W innych krajach występują takie plantacje, które są zakładane w bardzo dużych namiotach foliowych, gdzie drzewa rosną na stałe i takich, gdzie drzewka są wstawiane w doniczkach. Niektóre z plantacji są nawadniane, a nawet spryskiwane wodą w celu opóźnienia kwitnienia. Woda ochładza drzewko co powoduje późniejsze rozpoczęcie kwitnienia, niż innych drzew tego samego gatunku w okolicy. Ma to bardzo duże znaczenie, gdyż wtedy do plantacji nie dociera obcy pyłek. Pyłek z zewnątrz (obcy) o nieznanej wartości genetycznej zwykle obniża jakość nasion.

\section{Rozmieszczenie plantacji nasiennych w Polsce}

Liczba i rozmieszczenie plantacji nasiennych związane są z liczbą drzew matecznych na danym terenie oraz $z$ prowadzoną lokalnie gospodarką leśną. W północno-wschodniej Polsce na terenie RDLP Białystok, plantacje nasienne skoncentrowane są tylko w czterech, za to bardzo dużych kompleksach. Podobnie w RDLP Olsztyn. W Sudetach natomiast występują jedynie plantacje wegetatywne, a spora część z nich to plantacje zachowawcze, głównie jodły założone w ramach programu restytucji tego gatunku. Niewiele plantacji nasiennych znajduje się na południu Polski, w Bieszczadach i Beskidach (Kowalczyk et al. 2011: 18-20). Na tym terenie w większym stopniu wykorzystuje się odnowienie naturalne. Nie zakładano tam też popularnych w innych rejonach kraju plantacji nasiennych sosny, gdyż dominujące są tam gatunki liściaste i jodła. Niewielka jest również liczba plantacji nasiennych zlokalizowana na Pomorzu Zachodnim. W ostatnich latach powstało wiele obiektów plantacyjnych dla gatunków liściastych. W tabeli pierwszej zestawiono liczbę plantacji oraz podano powierzchnie plantacji wegetatywnych i generatywnych dla poszczególnych gatunków. Dotychczas założono 325 plantacji nasiennych, w tym 211 wegetatywnych, dla 22 gatunków drzew 
leśnych. Oczywiście nie oznacza to, że w Lasach Państwowych dla tych wszystkich gatunków realizuje się program hodowli selekcyjnej. Łączna powierzchnia plantacji nasiennych wynosi 2042 ha. Jest to bardzo duża baza nasienna, jedna $\mathrm{z}$ największych w Europie.

\section{Badania i prace naukowe na plantacjach nasiennych}

Naukowcy we współpracy z leśnikami mogą ocenić wartość hodowlaną drzew, bo - sam wygląd drzewa jeszcze o niczym nie świadczy. Zrazy są zbierane z najładniejszych, wyselekcjonowanych drzew o ładnym pokroju, które mają większy przyrost niż inne. Ale nic nie wiemy o ich genotypie. Czy one są dlatego ładne, że mają dobre cechy genetyczne, czy dlatego są ładne, że po prostu tak wyrosły, nikt im nie przeszkadzał, a z genetycznego punktu widzenia są przeciętne. Żeby się dowiedzieć jaką naprawdę mają wartość, leśnicy zakładają specjalne uprawy tzw. „testy potomstw" (Sabor 2003: 5-9). Plantacyjne uprawy nasienne powstające $\mathrm{z}$ nasion mogą być jednocześnie traktowane jako testy potomstwa do oceny wartości hodowlanej drzew matecznych reprezentowanych na uprawach (Kowalczyk 20o8: 126-134). Zgodnie z przyjętymi zasadami prowadzenia tych obiektów, przed wykonaniem cięć rozluźniających przeprowadza się ocenę cech ilościowych i jakościowych rosnących tam rodów. W oparciu o analizę uzyskanych wyników podejmuje się decyzję, o usunięciu najgorszych drzew. W ten sposób można podnieść genetyczną wartość plantacji.

Właściwe prowadzenie plantacji nasiennych, decyduje o tym, czy plantacje nasienne będą spełniały swoje zadanie, dlatego pielęgnacja szczepów lub sadzonek po ich wysadzeniu na powierzchni jest kluczowa dla ich prawidłowego wzrostu i kondycji. Częste monitorowanie plantacji umożliwia szybkie reagowanie na zauważone oznaki osłabienia lub złej kondycji drzewek. Niezmiernie istotne jest kontrolowanie wzrostu szczepów, zwłaszcza w początkowych latach po wysadzeniu, tak aby nie dopuścić do rozwoju odbitek z podkładki kosztem zaszczepionego zrazu z drzewa matecznego. Jest to szczególnie istotne w przypadku gatunków charakteryzujących się niska wydajnością szczepienia i trudnościami z przyjmowaniem się zrazu, jak dąb, buk czy klon. Dopuszczenie do rozwoju odbitki z podkładki, skutkujące najczęściej znacznym osłabieniem wzrostu zrazu lub jego całkowitym obumarciem, powoduje obecność na plantacji nieznanego, być może odznaczającego się niepożądanymi z hodowlanego punktu widzenia cechami, genotypu, który bierze udział w tworzeniu nasion na plantacji, obniżając tym samym jej efektywność (Gomory et al. 2003: 117-126).

Niewiele było badań realizowanych w kraju dotyczących plantacji nasiennych. W latach 2005-2009 w Instytucie Badawczym Leśnictwa analizowano możliwość zastosowania zabiegów ogławiających na plantacjach nasiennych sosny zwyczajnej, modrzewia europejskiego, lipy drobnolistnej, brzozy brodawkowatej oraz olszy czarnej. Badania obejmowały zróżnicowane typy obiektów pod względem wieku i pochodzenia wegetatywnego lub generatywnego, a także różne warianty intensywności cięć. Wyniki wskazują, że zabiegi ogławiające są skuteczną metodą ograniczania wzrostu drzew na wysokość, ale tylko wówczas, gdy zostaną zastosowane na młodych plantacjach nasiennych, na których szczepy lub drzewa nie zaczęły jeszcze stykać się ze sobą koronami i będą mogły zareagować na przycięcie górnej części korony intensyfikacją wzrostu pędów na boki. Ponadto dowiedziono, że istnieje konieczność powtarzania zabiegów w odstępach 2-3 lat (na plantacjach pochodzenia generatywnego częściej niż na plantacjach pochodzenia wegetatywnego), bowiem w przeciwnym wypadku ogłowione drzewa powrócą do wysokości sprzed zabiegu już po 3-4 latach, zwiększając jednocześnie liczbę pędów głównych powyżej miejsca cięcia. Intensywny wzrost nowych pędów przewodnich w celu odbudowania utraconej części korony powoduje ponadto zmniejszenie intensywności 
kwitnienia szczepów bądź drzew, skutkujące obniżeniem produkcji nasion. Jednorazowy zabieg ogławiający przynosi więc więcej szkód niż korzyści, a skuteczne mogą okazać się jedynie zabiegi systematycznie i konsekwentnie kontynuowane. Przed podjęciem decyzji o rozpoczęciu ogławiania na plantacji należy więc wykonać rzetelną analizę ekonomiczną, uwzględniającej wielkość zapotrzebowania na nasiona, koszty wykonywania zabiegów ogławiających oraz koszty zbioru nasion z nieogłowionych i ogłowionych drzew.

W przypadku niektórych gatunków (np. świerk pospolity) występują problemy z obradzaniem. Teoretycznie na plantacji nasiennej wszystkie rody krzyżują się ze sobą w równym stopniu, lecz rzeczywistość pokazuje, iż istnieje wiele odstępstw od tej teorii (Burczyk 1998: 155-157). Różnice te spowodowane są m.in: wiekiem rozpoczynania obradzania poszczególnych osobników, zmiennością fenologiczną i natężeniem kwitnienia, przewagą kwiatów męskich lub żeńskich u poszczególnych osobników. W związku z tym istnieje potrzeba przyspieszenia lub wyrównania momentu wchodzenia drzew w fazę kwitnienia, a w konsekwencji przyśpieszenia obradzania nasion. Stosując zabiegi stymulacji drzew można próbować regulować fenologię kwitnienia i pylenia poszczególnych osobników i jednocześnie wpływać na strukturę genetyczną nasion z plantacji. Stosowano bardzo zróżnicowane metody, poczynając od zmiany warunków mikroklimatycznych, wzrostu w warunkach szklarniowych (podwyższona temperatura, susza glebowa, zmiana oświetlenia, deficyt składników pokarmowych, ograniczanie wzrostu i podtapianie korzeni), poprzez nawożenie mineralne, zabiegi mechaniczne (obrączkowanie, opaski uciskowe, podcinanie korzeni, przycinanie i przyginanie gałęzi), aż po podawanie regulatorów wzrostu, głównie auksyn i giberelin. Skuteczność metod stymulujących kwitnienie była bardzo zróżnicowana, w dużym stopniu uzależniona od gatunku i wieku drzewa oraz sposobu i terminu zastosowania zabiegu. Najefektywniej stymulującymi kwitnienie metodami okazały się zabiegi mechaniczne, głównie obrączkowanie, a także podawanie regulatorów wzrostu, zwłaszcza mieszaniny giberelin GA4/7 (Bonnet-Masimbert et al. 1998: 195-202) (Almqvist 2003: 413-418) oraz zastosowanie łączne tych dwóch metod. Obrączkowanie polega na przecięciu kory i łyka pnia lub gałęzi. Celem tego zabiegu jest zakłócenie spływu asymilatów z igieł i pędów do korzeni i gromadzenie ich w zwiększonej ilości ponad obrączką. Obniżenie zawartości wody, azotu i fosforu przy jednoczesnym wzroście ilości nierozpuszczalnych węglowodanów (skrobi) i stężenia potasu w pędach powoduje, ze więcej tworzących się na pędach zawiązków przyszłych paków różnicuje się w paki generatywne a nie wegetatywne, co skutkuje większa intensywnością kwitnienia wiosna następnego roku.

Efektywność plantacji nasiennych i ich opłacalność była analizowana dla sosny zwyczajnej w Finlandii. Zarówno badania symulacyjne (Ahtikoski et al. 2012: 335-348) jak i badania porównawcze zrealizowanego zysku genetycznego (Haapanen et al. 2016: 997-1009) wykazały opłacalność ekonomiczną stosowania leśnego materiału rozmnożeniowego z plantacji nasiennych. Potwierdziły to również badania kanadyjskie dla drzewostanów świerka białego (Wu et at. 2015: 141-156). W Polsce brak jest takich badań. Z obserwacji praktyków zarówno w Polsce jak i innych krach (Ruotsalainen 2014: 333-344) wynika jednak, że uprawy powstałe $\mathrm{z}$ nasion pochodzących z PN wyróżniają się lepszym wzrostem i lepszymi cechami jakościowymi. Koszt nasion z plantacji nasiennych jest większy w porównaniu z nasionami z drzewostanów. Jednak ten koszt w produkcji sadzone jest nieznaczny i nie przekracza 3\% ceny sadzonki (informacja ustana od inż. Stanisław Słomiński Nadl. Gniewkowo 2017). Z pewnością warto ponieść większe koszty na zakup nasion o lepszej wartości genetycznej, gdyż zwróci się on wielokrotnie. 


\section{Wartościowanie i grupowanie plantacji nasiennych}

W celu oceny przydatności dla dalszej gospodarki w Lasach Państwowych zespół ekspertów powołany praz Dyrektora Lasów Państwowych oceniał stan 334 plantacji nasiennych zgodnie ze stanem na dzień 1 czerwca 2016 r. w rejestrze Systemu Informatycznego Lasów Państwowych w części Zasoby. Każdy obiekt był oceniany według kryteriów, które zostały opracowane przez zespół (tabela 1). Uwzględniono odrębność PN i PUN.

Wartość plantacji ocenia się przez sumowanie punktów dla poszczególnych kryteriów. Przy stosowaniu powyższych kryteriów przyjęto następujące założenia:

- Oddzielnie klasyfikuje się obiekty plantacyjne dla grup gatunków (So - sosna, Md - modrzew, Brz brzoza, Św - świerk, Dg - daglezja) i pozostałych.

- Faktyczny stan obiektu oceniony po lustracji na gruncie i jego zgodność z siedliskiem jest jednym z czynników determinujących ocenę.

- Zasięg wykorzystania nasion określono na podstawie obowiązujących reguł przemieszczania LMR (Rozporządzenie Ministra Środowiska Dz. U.1328. 2015: art. 2) jak i praktycznego wykorzystywania nasion.

- Wartość populacji, z której pochodzą drzewa mateczne do założenia plantacji jest określana na podstawie dostępnych publikacji i raportach $\mathrm{z}$ badań (zwykle niepublikowanych).

Zgodnie z ustaleniami ekspertów wszystkie plantacje podzielono na cztery grupy. Pierwszy podział dotyczył gatunku wysadzonego na plantacji nasiennej. Wydzielono grupę A z tzw. "gatunkami produkcyjnymi”, do których zaliczono: sosnę zwyczajną, świerk pospolity, modrzew europejski, daglezję zieloną i brzozę brodawkowatą oraz grupę B z pozostałymi gatunkami (do tej zaliczono również wszystkie plantacje zachowawcze). Drugi podział wewnątrz grup gatunków dotyczył typu plantacji. Osobno kategoryzowano plantacje nasienne klonowe (PN) i plantacje nasienne generatywne (PUN). Każda grupa miała dobrany indywidualny podział punktów granicznych pomiędzy kategoriami. Tak wiec kategoryzacja, chociaż ma elementy obiektywne, ma też

Tabela 1. Zestawienie kryteriów i przypisanych im wag w grupowaniu plantacji nasiennych

\begin{tabular}{|c|c|c|c|}
\hline Lp. & Kryteria & Opis wartości & Punkty \\
\hline \multirow[t]{2}{*}{1} & \multirow[t]{2}{*}{ Gatunek } & $\begin{array}{l}\text { Grupa gatunków dla których prowadzi się lub planuje się prowadzić } \\
\text { intensywniejsze prace selekcyjne (So, Md, Brz, Św, Dg) }\end{array}$ & 4 \\
\hline & & Pozostałe gatunki & 1 \\
\hline \multirow{2}{*}{2} & \multirow{2}{*}{ Wiek } & do 40 lat & 1 \\
\hline & & powyżej 40 lat & 0 \\
\hline \multirow{3}{*}{3} & \multirow{3}{*}{$\begin{array}{l}\text { Stan plantacji i jej } \\
\text { dostosowanie do } \\
\text { środowiska }\end{array}$} & $\begin{array}{l}\text { plantacje zgodne z siedliskiem, na których nie występują poważne szkody } \\
\text { związane z lokalizacją itp. }\end{array}$ & 3 \\
\hline & & plantacje częściowo zgodne z siedliskiem & 1 \\
\hline & & $\begin{array}{l}\text { plantacje niezgodne z siedliskiem, o dużych ubytkach i zniszczeniach, nie } \\
\text { dających się wyeliminować bez bardzo dużych nakładów środków }\end{array}$ & -5 \\
\hline \multirow{3}{*}{4} & \multirow{3}{*}{$\begin{array}{l}\text { Zasięg wykorzystania } \\
\text { nasion }\end{array}$} & bardzo duży, krajowy & 3 \\
\hline & & duży, regionalny & 2 \\
\hline & & Lokalny & 1 \\
\hline \multirow[b]{2}{*}{5} & \multirow{2}{*}{$\begin{array}{l}\text { Zmienność } \\
\text { genetyczna }\end{array}$} & efektywna liczba klonów wyższa/równa 20 & 1 \\
\hline & & efektywna liczba klonów niższa niż 20 & 0 \\
\hline \multirow{2}{*}{6} & \multirow{2}{*}{$\begin{array}{l}\text { Pochodzenie } \\
\text { materiału }\end{array}$} & obecny stan wiedzy charakteryzuje daną populację jako ponad przeciętną & 1 \\
\hline & & brak danych, inne & 0 \\
\hline
\end{tabular}




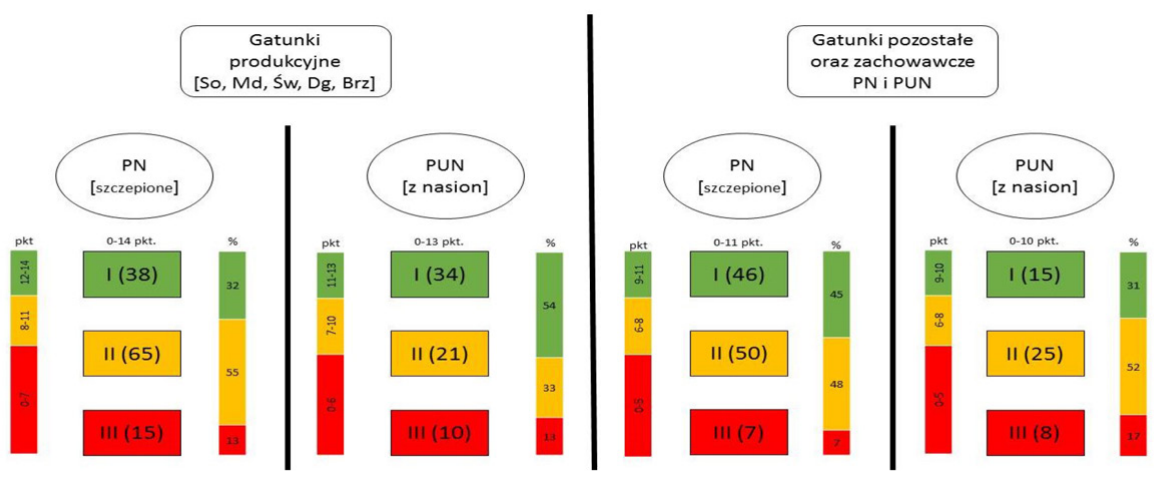

Ryc. 1. Schemat kategoryzacji plantacji nasiennych. W nawiasach podano liczbę obiektów w poszczególnych grupach i kategoriach wewnątrz grup

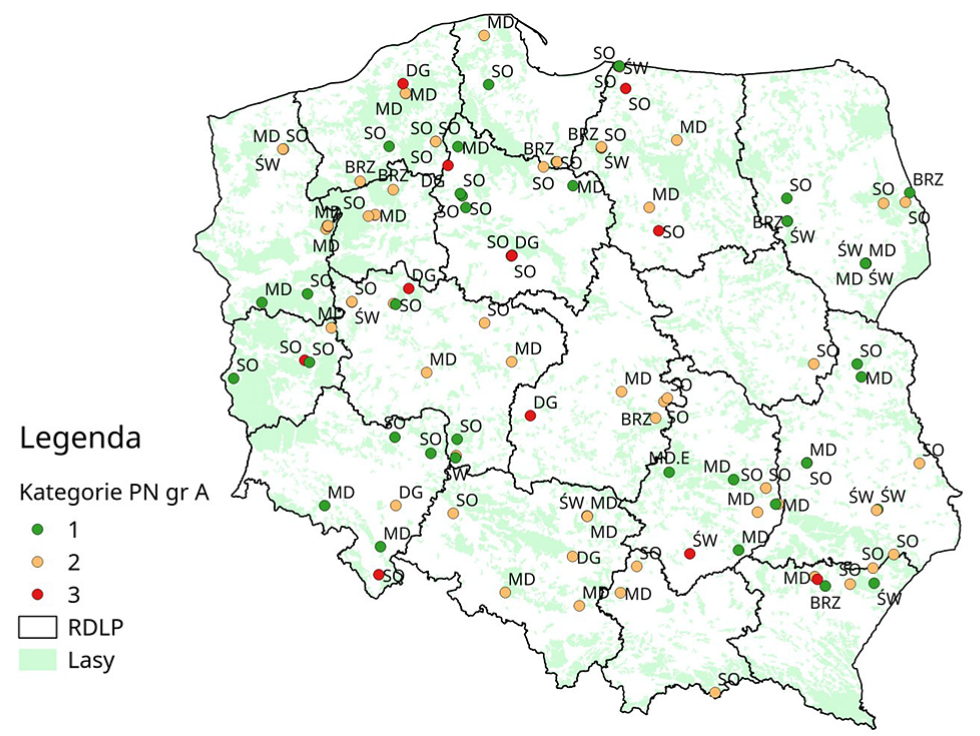

Ryc. 2. Rozmieszczenie w Polsce plantacji nasiennych sosny zwyczajnej (SO), modrzewia europejskiego (MD), świerka pospolitego (ŚW) i daglezji zielonej z podziałem na kategorie. Kategoria plantacji odzwierciedla głównie stan plantacji, a nie zysk genetyczny możliwy do osiągnięcia

charakter ekspercki wynikający z uwarunkowań występujących w Polsce.

Wszystkie plantacje podzielono na dwie grupy gatunków. Wewnątrz każdej z grup wydzielona jest podgrupa plantacji klonowych i rodowych (ryc. 1). Tak wydzielone grupy pogrupowano na 3 kategorie (na ryc. 1 zaznaczone kolorami). Przykładowo, pierwsza grupa plantacji nasiennych (klonowe plantacje nasienne gatunków produkcyjnych) była najbardziej liczna (118 szt.). Do I kategorii (najlepszej) zaliczono 38 obiektów, do II kategorii (przeciętnej) 65 obiektów, natomiast do III (najgorszej) 15 obiektów.
Stanowiły one odpowiednio 32, 55, 13 proc. ogółu plantacji w tej grupie. Analogicznie na rycinie 1 przedstawiono ogólny schemat kategoryzacji plantacji nasiennych.

Pogrupowanie plantacji nasiennych może być przydatne przy planowaniu gospodarki nasiennej w Lasach Państwowych. Nasiona z plantacji, powinny być wykorzystywane zgodnie z zasadą wielofunkcyjnej gospodarki leśnej, lecz przede wszystkim na powierzchniach, gdzie funkcja produkcyjna jest priorytetowa. Szczególnie odnosi się to do nasion z plantacji klonowych grupy A kategorii I. Stare plantacje będące w dobrej 
kondycji, z różnych względów są słabo użytkowane. Wynika to zarówno z trudności w pozyskiwaniu nasion $\mathrm{z}$ wysokich drzew jak i dostępności innych młodszych obiektów w regionie. W takim przypadku również warto rozważyć likwidacje plantacji a teren po zlikwidowanej plantacji warto wykorzystać pod plantację następnej generacji. Coraz trudniej jest, bowiem obecnie znaleźć powierzchnie nadające się pod plantacje. Wynika to zarówno z obowiązującego sposobu gospodarowania w lasach jak i z wymogu jak najlepszej izolacji plantacji przed pyłkiem dopływającym z sąsiedztwa. Plantacje w kategorii drugiej mogą być dalej wykorzystywane i należy podjąć takie działania, aby były one w miarę możliwości ulepszane i doprowadzane do jak najlepszej kondycji. Wyniki kategoryzacji wskazują, że pośród pierwszej grupy gatunków w trzeciej kategorii znalazło się 25 plantacji. Obiekty te w zasadzie powinny być przeznaczone do likwidacji. Wynika to głównie z ich stanu na gruncie ocenionym jako trudny do przywrócenia do funkcjonalności.

\section{Wnioski końcowe}

Lepszej jakości plantacje nasienne są po to, aby powstały z nich las produkował więcej dobrego drewna i wykazywał większą stabilność. Są one efektywne i ekonomicznie opłacalne, w porównaniu do tego, jakie zadanie mają do wypełnienia w leśnictwie. Jak wynika z analiz zwiększenie kosztów produkcji sadzonek, w związku z użyciem nasion z plantacji nasiennych, nie przekracza 3\%. Dlatego sady nasienne (plantacje) są najbardziej racjonalną i najmniej ekologicznie wątpliwą drogą do poprawy produkcji leśnej. Aby osiągnąć wykorzystanie 40\% nasion z plantacji nasiennych w odnowieniach i zalesieniach należy zintensyfikować i zoptymalizować użytkowanie plantacji nasiennych dla głównych gatunków lasotwórczych. Analiza stanu plantacji nasiennych, jakie dają wyniki grupowania, może być wykorzystana przy planowaniu hodowlanym w gospodarce leśnej.

\section{Bibliografia}

Ahtikoski, A., Ojansuu, R. Haapanen, M. Hynynen, J. Kärkkäinen, K. 2012. "Financial Performance of Using Genetically Improved Regeneration Material of Scots Pine (Pinus Sylvestris L.) in Finland." New Forests 43 (3): 335-48. doi:10.1007/ S11056-011-9284-6.

Almqvist, C. 2003. "Timing of GA 4 / 7 Application and the Flowering of Pinus Sylvestris Grafts in the Greenhouse," no. June: 413-18.

Bonnet-Masimbert, M., Baldet, P., Pâques, L. E., Philippe, G. 1998. "From Flowering to Artificial Pollination in Larch for Breeding and Seed Orchard Production." Forestry Chronicle 74 (2): 195-202.

Burczyk, J. 1998. „Mating system variation in a Scots pine clonal seed orchard." Silvae Genetica, 47(2), 155-157.

Chałupka, W, Matras, J, Barzdajn, W, Blonkowski, S., Burczyk, J, Fonder, W, Grądzki, T, i in. 2011. "Program Zachowania Leśnych Zasobów Genowych i Hodowli Selekcyjnej Drzew Leśnych w Polsce Na Lata 2011-2035." Warszawa: Centrum Informacyjne Lasów Państwowych, 1-142.

Chybicki, I, J, Burczyk. J. 2013. "Seeing the Forest through the Trees: Comprehensive Inference on Individual Mating Patterns in a Mixed Stand of Quercus Robur and Q. Petraea." Annals of Botany 112 (3): 561-74. doi:10.1093/aob/mct131.

Faulkner, Roy. 1975. "Seed Orchards." Forestry Commision BULLETIN. London, 1-180.

Gomory, Dusan, Rudolf Bruchanik, and Roman Longauer. 2003. "Fertility Variation and Flowering Asynchrony in Pinus Sylvestris : Consequences for the Genetic Structure of Progeny in Seed Orchards `an Go." Forest Ecology and Management 174: 117-26.

Haapanen, Matti, Jari Hynynen, Seppo Ruotsalainen, Jouni Siipilehto, and Marja Leena Kilpeläinen. 2016. "Realised and Projected Gains in Growth, Quality and Simulated Yield of Genetically Improved Scots Pine in Southern Finland." European Journal of Forest Research 135 (6): 997-1009. doi:10.1007/s10342-016-0989-o.

Ivetić, V, Devetaković, J, Nonić, M. 2016. “Genetic Diversity and Forest Reproductive Material from Seed Source Selection to Planting," no. June. doi:10.3832/ifor1577-009.

Kowalczyk, J. 2008. "Combining Production of Improved Seeds with Genetic Testing in Seedling 
Seed Orchards." Seed Orchards Proceedings from a Conference at Umea Sweden 2628 September 2007, no. 3: 126-34. http://www-genfys.slu.se/staff/ dagl/Umeao7/ZProcFinalFebo8.pdf.

Kowalczyk, J, Markiewicz, P, Chałupka, W, Matras, J. 2011. "Plantacje Nasienne - Rola i Znaczenie w Gospodarce Leśnej.” Las Polski, no. 22: 18-20. MINISTER ŚRODOWISKA. 2015. "ROZPORZĄDZENIE MINISTRA ŚRODOWISKA z Dnia 29 Lipca 2015 r. w Sprawie Wykorzystywania Leśnego Materiału Rozmnożeniowego Poza Regionem Pochodzenia Na." DZIENNIK USTAW RZECZYPOSPOLITEJ POLSKIEJ 1328 (9): 1289-96.

Ruotsalainen, S. 2014. "Increased Forest Production through Forest Tree Breeding." Scandinavian Journal of Forest Research 29 (4). Taylor \& Francis: 333-44. doi:10.108o/o2827581.2014.926100.
Sabor, J. 2002. “Czemu Służy Genetyka Leśna.” Głos Lasu, no. 1: 5-9.

Wu, Y. Q., Y. H. Weng, C. Hennigar, M. S. Fullarton, and V. Lantz. 2015. "Benefit-cost Analysis of a White Spruce Clonal Seed Orchard in New Brunswick, Canada." New Forests 46 (1): 141-56. doi:10.1007/s11056-014-9453-5.

Zobel, B.J., J Barber, C.L. Brown, and Perry T.O. 1958. "Seed Orchards - Their Concept and Management." Journal of Forestry 56 (11): 815-25.

OECD scheme for the control of forest reproductive material moving in international trade. 2001. Organization for Economic Co-operation and Development, Paris 1974 (including 2001 amendment): 1-28.

\section{Seed orchards in Poland}

\section{Abstract}

Polish forests have multiple functions, from the provision of spaces for leisure and recreation and conservation of nature and biodiversity to the creation of wealth and employment and the production of natural resources and raw materials for industry and bioenergy production. This multi-functionality creates conflicts between different uses and stakeholders. As the durability of wood use is inextricably linked to tree breeding, the basic tool for accomplishing these tasks is breeding programmes for forest trees, and one of the important elements in tree breeding activities is the seed orchards. In this review article, we present the state of the art of seed orchards in Poland and their grouping according to importance in forest management. We include historical facts regarding the creation of the idea of seed orchards and its implementation in forest breeding practice. When we manage seed orchards, on the one hand, we care about genetic variability, and on the other hand, we aim for genetic gain. Seed orchards are effective and economically viable for their role in forestry. According to economic studies, the increase in seedling production costs in connection with the use of seeds from seed orchards, does not exceed $3 \%$. According to the authors, seed orchards are the most rational and least ecologically risky way to improve forest production.

\section{Keywords}

seed orchards, forest tree breeding, genetic gain, biodiversity, classification of seed orchards 